NASA/TM-2002-211873

2002137608

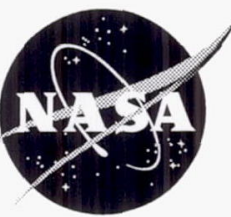

\title{
A Multilayered Thin Film Insulator for Harsh Environments
}

John D. Wrbanek and Gustave C. Fralick

Glenn Research Center, Cleveland, Ohio

Charles A. Blaha

Akima Corporation, Brook Park, Ohio

A. Rachel Busfield

Rolls-Royce plc, Derby, United Kingdom

Valarie D. Thomas

Ohio Aerospace Institute, Brook Park, Ohio 
Since its founding, NASA has been dedicated to the advancement of aeronautics and space science. The NASA Scientific and Technical Information (STI) Program Office plays a key part in helping NASA maintain this important role.

The NASA STI Program Office is operated by Langley Research Center, the Lead Center for NASA's scientific and technical information. The NASA STI Program Office provides access to the NASA STI Database, the largest collection of aeronautical and space science STI in the world. The Program Office is also NASA's institutional mechanism for disseminating the results of its research and development activities. These results are published by NASA in the NASA STI Report Series, which includes the following report types:

- TECHNICAL PUBLICATION. Reports of completed research or a major significant phase of research that present the results of NASA programs and include extensive data or theoretical analysis. Includes compilations of significant scientific and technical data and information deemed to be of continuing reference value. NASA's counterpart of peerreviewed formal professional papers but has less stringent limitations on manuscript length and extent of graphic presentations.

- TECHNICAL MEMORANDUM. Scientific and technical findings that are preliminary or of specialized interest, e.g., quick release reports, working papers, and bibliographies that contain minimal annotation. Does not contain extensive analysis.

- CONTRACTOR REPORT. Scientific and technical findings by NASA-sponsored contractors and grantees.
- CONFERENCE PUBLICATION. Collected papers from scientific and technical conferences, symposia, seminars, or other meetings sponsored or cosponsored by NASA.

- SPECIAL PUBLICATION. Scientific, technical, or historical information from NASA programs, projects, and missions, often concerned with subjects having substantial public interest.

- TECHNICAL TRANSLATION. Englishlanguage translations of foreign scientific and technical material pertinent to NASA's mission.

Specialized services that complement the STI Program Office's diverse offerings include creating custom thesauri, building customized databases, organizing and publishing research results ... even providing videos.

For more information about the NASA STI Program Office, see the following:

- Access the NASA STI Program Home Page at http://www.sti.nasa.gov

- E-mail your question via the Internet to help@sti.nasa.gov

- Fax your question to the NASA Access Help Desk at 301-621-0134

- Telephone the NASA Access Help Desk at 301-621-0390

- Write to: NASA Access Help Desk NASA Center for AeroSpace Information 7121 Standard Drive Hanover, MD 21076 
NASA/TM-2002-211873

AIAA-2002-3731

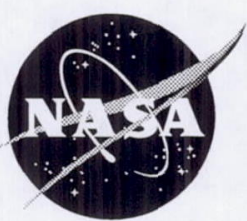

\section{A Multilayered Thin Film Insulator for Harsh Environments}

John D. Wrbanek and Gustave C. Fralick

Glenn Research Center, Cleveland, Ohio

Charles A. Blaha

Akima Corporation, Brook Park, Ohio

A. Rachel Busfield

Rolls-Royce plc, Derby, United Kingdom

Valarie D. Thomas

Ohio Aerospace Institute, Brook Park, Ohio

Prepared for the

38th Joint Propulsion Conference and Exhibit cosponsored by AIAA, ASME, SAE, and ASEE

Indianapolis, Indiana, July 7-10, 2002

National Aeronautics and

Space Administration

Glenn Research Center 


\section{Acknowledgments}

The authors would like to acknowledge the assistance of Drago Androjna (Akima Corporation) and Dorothy Lukco (QSS Group, Inc.) for the EDAX and Auger analysis of the samples. This work was pursued under the Information

Rich Test Instrumentation (IRTI) project, part of NASA's Advanced Space Transportation Program (ASTP). The authors would also like to acknowledge the support of the management of NASA Glenn Research Center, together with Rolls-Royce and Allison Advanced Development Company, for arranging this collaboration. Additional funding was provided by Rolls-Royce and the Royal Academy of Engineering.

This report is a formal draft or working paper, intended to solicit comments and ideas from a technical peer group.

This report contains preliminary findings, subject to revision as analysis proceeds.

The Aerospace Propulsion and Power Program at NASA Glenn Research Center sponsored this work.

Available from

NASA Center for Aerospace Information 7121 Standard Drive

Hanover, MD 21076
National Technical Information Service 5285 Port Royal Road Springfield, VA 22100 


\title{
A MULTILAYERED THIN FILM INSULATOR FOR HARSH ENVIRONMENTS
}

\author{
John D. Wrbanek and Gustave C. Fralick \\ National Aeronautics and Space Administration \\ Glenn Research Center \\ Cleveland, Ohio 44135 \\ Charles A. Blaha \\ Akima Corporation \\ Brook Park, Ohio 44142 \\ A. Rachel Busfield \\ Rolls-Royce plc, \\ Derby DE24 8BJ, United Kingdom \\ Valarie D. Thomas \\ Ohio Aerospace Institute \\ Brook Park, Ohio 44142
}

\begin{abstract}
The status of work to develop a reliable high temperature dielectric thin film for use with thin film sensors is presented. The use of thin films to electrically insulate thin film sensors on engine components minimizes the intrusiveness of the sensor and allows a more accurate measurement of the environment. A variety of insulating films were investigated for preventing electrical shorting caused by insulator failure between the sensor and the component. By alternating layers of sputtered high temperature ceramics, a sequence of insulating layers was devised that prevents pinholes from forming completely through the insulator and maintains high electrical resistivity at high temperatures. The major technical challenge remaining is to optimise the fabrication of the insulator with respect to composition to achieve a reliable high temperature insulating film. Data from the testing of various potentially insulating thin film systems is presented and their application to thin film sensors is also discussed.
\end{abstract}

\section{Introduction}

As part of NASA Glenn Research Center's mission to develop critical technologies that enable safer, lighter, quieter, and more fuel efficient vehicles for aeronautics and space transportation, the Sensors and Electronics Technology Branch has an effort to develop thin film sensors for surface measurement in propulsion system research. The sensors include those for strain, temperature, heat flux and surface flow.
Rolls-Royce plc provides power systems for air and marine propulsion and industrial applications. The Instrumentation Engineering department is developing thin film sensor technologies to support the company's drive for designing and manufacturing systems having increased safety and durability while minimizing noise and emissions.

The use of thin film sensors has several advantages over wire or foil sensors. The thin film sensors do not require special machining of the components on which they are mounted, and, with thickness less than $10 \mu \mathrm{m}$, they are considerably thinner than wire or foils. The thin film sensors are thus much less disturbing to the operating environment, and have a minimal impact on the physical characteristics of the supporting component. Several thin film sensors have been tested up to $1100{ }^{\circ} \mathrm{C}$ in different engine conditions at NASA Glenn Research Center. ${ }^{1,2}$

Fabricating metal sensors directly on metal components requires the use of an electrically insulating layer between the component and the sensor. Flame-sprayed insulators provide good insulating capability, but the thickness of the coatings ( $300 \mu \mathrm{m}$ and greater due to the coating porosity) lessens the advantage of the thin film sensor. NASA Glenn Research Center has been examining the use of thin film insulators as an alternative. One process developed utilizes a $125 \mu \mathrm{m}$ thick NiCoCrAlY base coat on which alumina can be thermally grown and vapor-deposited. ${ }^{3}$ Rolls-Royce thin film sensors use a reactively-sputtered layer of alumina to provide the electrical insulation. 
The application of alternative thin film dielectric insulators has been examined to further minimize the insulation thickness. However, ceramics lose their electrical insulation exponentially with increasing temperatures. Short circuit paths at grain boundaries and film defects can further reduce the insulation properties from the bulk values at high temperatures.

To further this research, NASA Glenn Research Center and Rolls-Royce have pursued a joint investigation of utilizing multilayered thin film dielectrics as a reliable insulator for use in harsh environments. The use of a multilayered scheme is thought to be promising for the fabrication of electrically insulating thin films. A major cause of conduction in thin film dielectrics is the presence of defects, such as pinholes, that propagate clear through the film to the underlining substrate surface. By alternating the insulating material, a new growth pattern would eliminate the previous one. Thus, direct pathways for conduction to the substrate are eliminated. The requirements for such an insulator are driven by the environments of aerospace applications, which currently require insulation of $100 \mathrm{k} \Omega$ or better to $1100{ }^{\circ} \mathrm{C}$ in oxidizing conditions.

\section{Sample Preparation}

The film depositions were conducted in the Microsystems Fabrication Cleanroom facility at NASA Glenn Research Center. Several samples of multilayered insulators were generated using alumina and stainless steel shims as the test substrates. The alumina substrates provide readily available test beds that remain intact for the severe heating required of these films, up to $1700{ }^{\circ} \mathrm{C}$ if necessary. The stainless steel substrates can be annealed to $1000{ }^{\circ} \mathrm{C}$, and the thermal expansion of the steel should produce stresses similar to those that the film would experience on an engine component at that temperature.

After surfactant cleaning, the test shims were rinsed in acetone and then methanol. A schematic of the typical layer sequence of the test samples is illustrated in Figure 1. A layer of platinum $1 \mu \mathrm{m}$ thick was sputter deposited over the shims. On the alumina substrates, the platinum base coat insured the detection of a conduction path if one were to exist in the insulator. On the stainless steel substrates, the platinum base coat assisted in the bonding of the dielectrics to the metal. The dielectrics were then deposited with a total thickness of $5 \mu \mathrm{m}$. On top of the dielectric, several $4.75 \mathrm{~mm}$ diameter platinum pads were sputter deposited to simulate thin film sensors. The pads were deposited $5 \mu \mathrm{m}$ thick to insure that any cracks or pinholes were sufficiently filled to reveal any conduction paths. A room temperature resistance check was then performed to verify insulating capability of the sample.

Lead wires were connected to the platinum pads on the insulating samples to afford high temperature testing in an annealing oven. The platinum wires were parallelgap welded to the pads, which were then soldered to leads outside of the test oven. The oven was ramped at approximately $450{ }^{\circ} \mathrm{C} /$ hour while the resistance between the pads and the temperature measured by a type $\mathrm{K}$ thermocouple near the sample was monitored. The maximum resistance readable was $100 \mathrm{M} \Omega$. One cycle was performed to stabilize the sample, and the data from the second ramp was used for insulator evaluation.

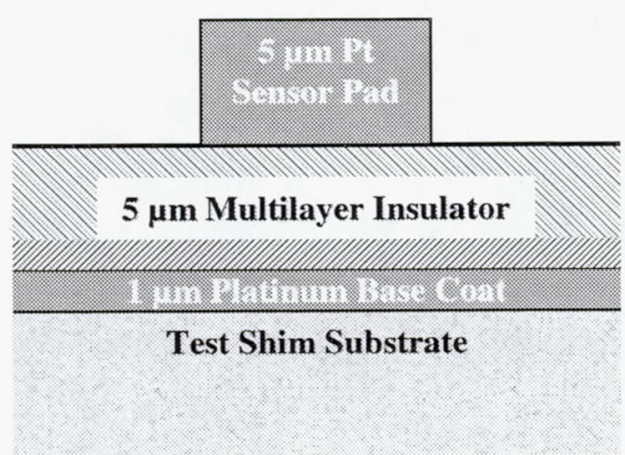

Figure 1.-Schematic of Insulator Test Sample

\section{Analysis}

A lettering scheme was used to identify specific samples of the study. The results of our sample tests are shown in Table 1 . The runs were lettered as they were planned, and, as failures and successes dictated, some runs were skipped. The first three runs of samples set the baseline for the work.

The samples from run $A$ had a single layer of $5 \mu \mathrm{m}$ alumina $\left(\mathrm{Al}_{2} \mathrm{O}_{3}\right)$ sputter deposited at room temperature. The samples indicated a short at room temperature, verifying the need for a more complex insulating thin film structure to achieve the required insulating capabilities for a $5 \mu \mathrm{m}$ film.

The next samples (run B) tested used an underlying layer of $1 \mu \mathrm{m}$ thick silica $\left(\mathrm{SiO}_{2}\right)$ sputter deposited, with an upper layer of $4 \mu \mathrm{m}$ alumina sputter deposited at room temperature. These samples showed insulating properties at high temperature, with the sample on stainless steel several orders of magnitude more conducting than that on alumina. Both samples showed significant cracking after heat treatment. The samples 
also showed a severe hysteresis in their resistance curves during the heat cycle. Despite the poor insulation properties, the run validated the concept of using a multilayer structure to eliminate conduction paths to the substrate that caused the short in run $\mathrm{A}$ samples.

Samples in run $\mathrm{C}$ were composed of a bottom layer of $2 \mu \mathrm{m}$ alumina, followed by $1 \mu \mathrm{m}$ of silica, and then covered with $2 \mu \mathrm{m}$ of alumina sputter deposited on stainless steel shims. These samples showed properties similar to those of the run B samples on stainless steel, but with more severe cracking of the surface. Figure 2 shows the cracking seen on a typical sample from run $\mathrm{C}$ on stainless steel.

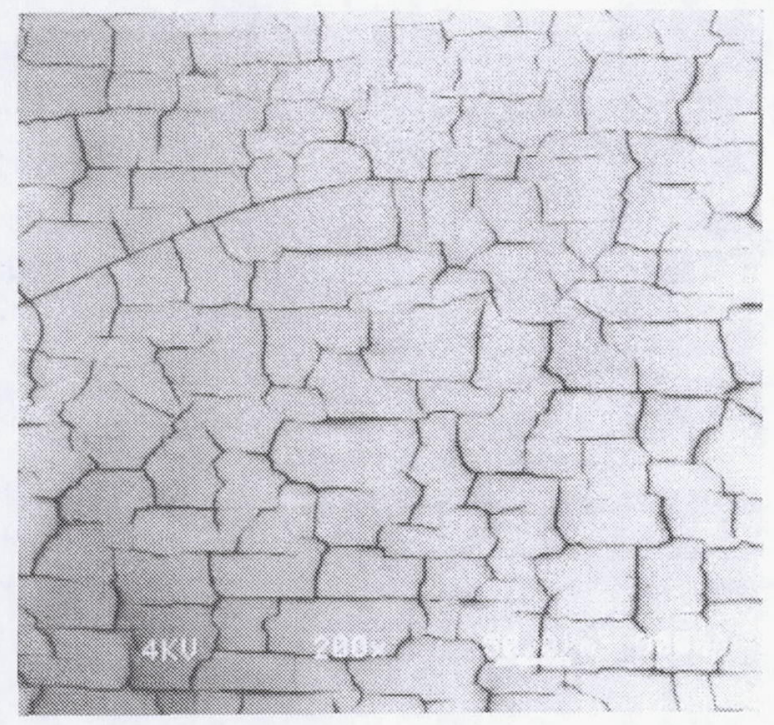

Figure 2.-Cracking on the surface of sample from Run $\mathrm{C}\left(\mathrm{Al}_{2} \mathrm{O}_{3}-\mathrm{SiO}_{2}-\mathrm{Al}_{2} \mathrm{O}_{3}\right.$ Multilayer $)$ after heat cycling to $500{ }^{\circ} \mathrm{C}$. The width of the image is approximately $525 \mu \mathrm{m}$.

Several samples were prepared to further investigate the cause of the cracking. EDAX analysis of an annealed silica sample revealed that chromium and iron from the steel were migrating into the cracks formed in the films when heated. The deposition of the alumina by e-beam vaporization at $800{ }^{\circ} \mathrm{C}$ resulted in room temperature shorts. Surface preparation was altered to smooth the stainless steel by $\mathrm{H}_{2} \mathrm{SO}_{4} / \mathrm{H}_{2} \mathrm{O}_{2}$ cleaning. However, the poor film adhesion to the substrate surface and the high conductivity of the resulting film terminated this path.

Two alternatives to using silica as an underlying layer were tested and the results were promising. Run R used $1 \mu \mathrm{m}$ of sputtered chromium carbide followed by $4 \mu \mathrm{m}$ of e-beamed alumina, and run $\mathrm{S}$ used $1 \mu \mathrm{m}$ of sputtered yttria-stabilized zirconia followed by $4 \mu \mathrm{m}$ of e-beamed alumina. The platinum base coat was not deposited for run $\mathrm{R}$ since the chromium carbide proved to be an excellent bond coat between chromium-containing metals and oxide ceramics. Figure 3 shows the pinholefree surface of a run $\mathrm{R}$ sample after heat-treating to $800{ }^{\circ} \mathrm{C}$ on a steel substrate. The temperature limit of both insulators for $100 \mathrm{k} \Omega$ of resistance appears to be about $1000{ }^{\circ} \mathrm{C}$ for the $5 \mu \mathrm{m}$ of material deposited. The zirconia-alumina insulator was deposited on a steel substrate in run $\mathrm{T}$, but the alumina failed before any data could be gathered.

The data from the temperature ramps of runs $\mathrm{B}, \mathrm{C}, \mathrm{R}$, and $S$ are plotted in figure 4. To give a quantitative comparison of the insulators, the data were fit to exponential decay curves. The results of the fittings are given in table 2 , which gives the estimated $0^{\circ} \mathrm{C}$ values, decay constants, minimum use temperatures and uncertainties.

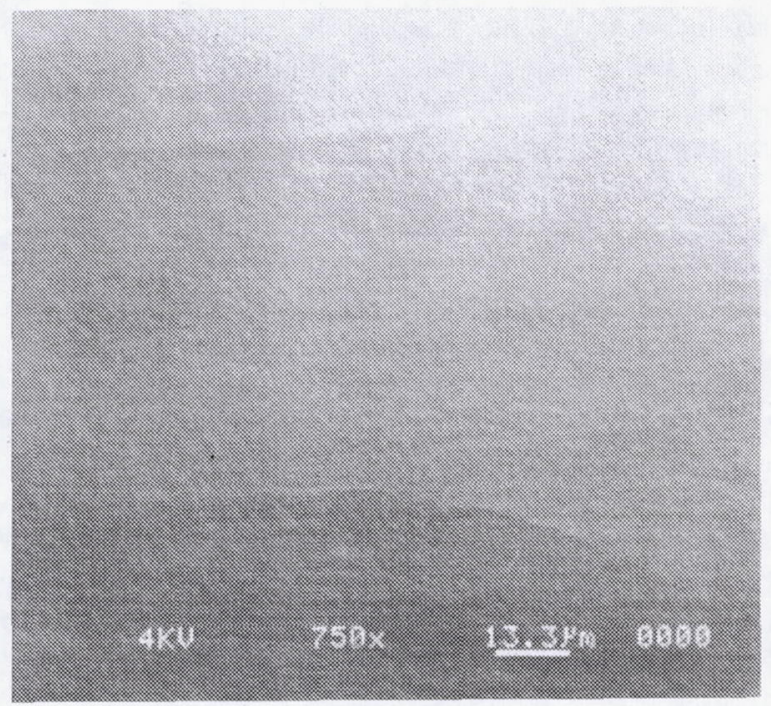

Figure 3.-Pinhole-free surface of sample from Run R $\left(\mathrm{Cr}_{3} \mathrm{C}_{2}-\mathrm{Al}_{2} \mathrm{O}_{3}\right.$ Multilayer) after heat cycling to $800^{\circ} \mathrm{C}$. The width of the image is approximately $140 \mu \mathrm{m}$.

\section{Conclusions}

The results of this study indicate that the CTE mismatch between silica and metals inhibits its use as an effective thin film insulating layer or under layer for alumina. The CTE's of various materials used in these tests are given in the bulk properties listing in table 3 . It is clear from these tests that a silica under layer does not expand freely enough to be used in a thin film 
multilayer insulator sequence on metals, particularly when e-beam depositing the alumina at $800^{\circ} \mathrm{C}$. Even following a $500{ }^{\circ} \mathrm{C}$ annealing cycle, the silica cracking is sufficient to permit chromium and iron migration from the steel into the thin film insulation. In fact, under the $800^{\circ} \mathrm{C}$ e-beam deposition temperatures of the alumina, the CTE mismatch between the steel and the silica is sufficient to cause cracking in the insulating film and adhesion failures.

The slightly lower CTE of yttria-stabilized zirconia may account for the stresses observed in the alumina thin film when the layers were applied to the steel substrate in run $\mathrm{T}$. It should be noted that since most engine components are "super-alloys" similar to Hastelloy or Inconel with CTE's between 10 and $13 \mathrm{ppm} /{ }^{\circ} \mathrm{C},{ }^{4}$ the zirconia-alumina multilayer may be applicable for use on those materials.

The success of run $\mathrm{R}$ is attributed to the graded interface between the chromium carbide and the chromium-containing metal. The intimate contact is believed to induce chemical-level bonding between the two materials. Thus, adhesion is promoted even at high temperatures. Further, the CTE of chromium carbide is intermediate between the alumina and the steel, thus grading the thermal stresses that would be produced during heating. Systematic Auger analysis of the chrome carbide chemistry is ongoing.

Ultimately, the goal is to use the multilayer insulator on a real engine component. The next challenge in this investigation is to optimize the chromium carbidealumina multilayer on nickel-based "super-alloy" test shims for use on these engine components. Testing of the zirconia-alumina multilayer on these test shims may also give more insight on the thin film chemistry of these multilayer insulators.

\section{References}

1. J.F. Lei, L.C. Martin, H.A. Will, "Advances in Thin Film Sensor Technologies for Engine Applications," NASA TM-107418, Turbo Expo '97, Orlando, FL, June 2-5, 1997.

2. L.C. Martin, J.D. Wrbanek, G.C. Fralick, "Thin Film Sensors for Surface Measurements," NASA TM-2001-211149, $19^{\text {th }}$ International Congress on Instrumentation in Aerospace Simulation Facilities, Cleveland, OH, August 27-30, 2001.

3. L.C. Martin, G.C. Fralick, K.F. Taylor, "Advances in Thin Film Thermocouple Durability Under High Temperature and Pressure Testing Conditions," NASA TM-1999-208812, January 1999.

4. CRC Handbook of Chemistry and Physics, edited by R.C. Weast and M.J. Astle, CRC Press (1982).

5. S.W Bradstreet, "Oxide Ceramics," HighTemperature Materials and Technology, edited by I.E. Campbell and E.M. Sherwood, The Electrochemical Society Series, John Wiley \& Sons, New York (1967), p. 235-303.

6. J. H. Westbrook and E.R. Stover, "Carbides for High-Temperature Materials," High-Temperature Materials and Technology, edited by I.E. Campbell and E.M. Sherwood, The Electrochemical Society Series, John Wiley \& Sons, New York (1967), p. 312-348. 
TABLE 1.-RUNS AND MULTILAYER SAMPLES GENERATED IN THIS EFFORT

Complete resistance data for runs B, C, R and S are plotted in Figure 4.

\begin{tabular}{|c|c|c|c|c|}
\hline Run & Substrates & Preparation & Multilayer & Result \\
\hline A & $\begin{array}{l}\text { Alumina } \\
\& \text { SS Shims }\end{array}$ & Silica Polish & $\begin{array}{c}5 \mu \mathrm{m} \mathrm{Al}_{2} \mathrm{O}_{3} \\
\text { sputter deposited }\end{array}$ & Short @ RT \\
\hline B & $\begin{array}{l}\text { Alumina \& } \\
\text { SS Shims }\end{array}$ & Silica Polish & 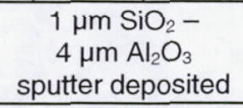 & $\begin{array}{l}\text { Film Cracks after } 500^{\circ} \mathrm{C} \text { Heat Treatment. } \\
\text { Alumina Shim: } 100 \mathrm{M} \Omega @ 720^{\circ} \mathrm{C}, 1.78 \mathrm{M} \Omega @ 1000{ }^{\circ} \mathrm{C} \\
\text { SS Shim: } 56 \mathrm{M} \Omega @ 41^{\circ} \mathrm{C}, 1 \mathrm{k} \Omega @ 440^{\circ} \mathrm{C}\end{array}$ \\
\hline C & SS & Silica Polish & $\begin{array}{c}2 \mu \mathrm{m} \mathrm{Al}_{2} \mathrm{O}_{3}- \\
1 \mu \mathrm{m} \mathrm{SiO}_{2}- \\
2 \mu \mathrm{m} \mathrm{Al}_{2} \mathrm{O}_{3} \\
\text { sputter deposited }\end{array}$ & $\begin{array}{c}\text { Film Cracks after } 500^{\circ} \mathrm{C} \text { Heat Treatment } \\
100 \mathrm{M} \Omega @ 17^{\circ} \mathrm{C}, 2 \mathrm{k} \Omega @ 500^{\circ} \mathrm{C}\end{array}$ \\
\hline$J$ & SS & Silica Polish & $\begin{array}{c}1 \mu \mathrm{m} \mathrm{SiO} \\
\text { sputter deposited }\end{array}$ & $\begin{array}{l}\text { EDAX after } 800^{\circ} \mathrm{C} \text { anneal indicates substantial } \mathrm{Cr} \& \mathrm{Fe} \\
\text { migrating from the SS into the cracks }\end{array}$ \\
\hline$M \& N$ & SS & Silica Polish & 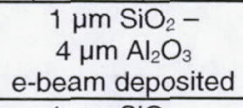 & Short@RT \\
\hline$P \& Q$ & SS & $\begin{array}{l}\mathrm{H}_{2} \mathrm{SO}_{4} / \mathrm{H}_{2} \mathrm{O}_{2} \\
\text { Cleaning }\end{array}$ & $\begin{array}{c}1 \mu \mathrm{m} \mathrm{\textrm {SiO } _ { 2 } -} \\
4 \mu \mathrm{m} \mathrm{Al} \mathrm{O}_{3} \\
\text { e-beam deposited }\end{array}$ & $\begin{array}{l}\text { Film Adhesion Failures } \\
\text { Short @ RT }\end{array}$ \\
\hline $\mathrm{R}$ & SS & $\begin{array}{l}\mathrm{H}_{2} \mathrm{SO}_{4} / \mathrm{H}_{2} \mathrm{O}_{2} \\
\text { Cleaning }\end{array}$ & $\begin{array}{c}1 \mu \mathrm{m} \mathrm{CrC}- \\
4 \mu \mathrm{m} \mathrm{Al} \mathrm{O}_{3} \\
\text { e-beam deposited }\end{array}$ & $\begin{array}{l}\text { Good Insulator } \\
84 \mathrm{M} \Omega @ 690^{\circ} \mathrm{C}, 20 \mathrm{M} \Omega @ 750^{\circ} \mathrm{C}\end{array}$ \\
\hline$S$ & Alumina & Silica Polish & $\begin{array}{c}1 \mu \mathrm{m} \mathrm{ZrO} \mathrm{Zr}_{2} \mathrm{Y}_{2} \mathrm{O}_{3}- \\
4 \mu \mathrm{m} \mathrm{Al} \mathrm{O}_{3} \\
\text { e-beam deposited }\end{array}$ & $\begin{array}{c}\text { Good Insulator } \\
50 \mathrm{M} \Omega @ 690^{\circ} \mathrm{C}, 17 \mathrm{M} \Omega @ 750^{\circ} \mathrm{C}, 1.8 \mathrm{M} \Omega @ 900^{\circ} \mathrm{C}\end{array}$ \\
\hline$T$ & SS & Silica Polish & $\begin{array}{c}1 \mu \mathrm{m} \mathrm{ZrO} \mathrm{Zr}_{2} \mathrm{Y}_{2} \mathrm{O}_{3}- \\
4 \mu \mathrm{m} \mathrm{Al} \mathrm{O}_{3} \\
\text { e-beam deposited }\end{array}$ & Film Adhesion Failure \\
\hline
\end{tabular}

TABLE 2.-ESTIMATES OF THE THERMAL PROPERTIES OF SELECTED MULTILAYER INSULATORS

$\left(\mathrm{R}=\mathrm{R}_{0} *^{-\mathrm{T} / \theta}\right.$ fit to Figure 4 data)

\begin{tabular}{|c|c|c|c|c|c|c|}
\hline Run & Multilayer & Substrate & $\frac{\text { Resistance }}{@ 0^{\circ} \mathrm{C}\left(\mathrm{R}_{0}\right)}$ & $\begin{array}{c}\text { Decay } \\
\text { Constant }(\theta) \\
\end{array}$ & Max Use Temp & \pm \\
\hline B & $\mathrm{SiO}_{2}-\mathrm{Al}_{2} \mathrm{O}_{3}$ & $\mathrm{Al}_{2} \mathrm{O}_{3}$ & $3.85 \mathrm{E}+6 \mathrm{M} \Omega$ & $65^{\circ} \mathrm{C}$ & $1140^{\circ} \mathrm{C}$ & $42 \%$ \\
\hline B & $\mathrm{SiO}_{2}-\mathrm{Al}_{2} \mathrm{O}_{3}$ & SS & $184 \mathrm{M} \Omega$ & $34^{\circ} \mathrm{C}$ & $260^{\circ} \mathrm{C}$ & $17 \%$ \\
\hline C & $\mathrm{Al}_{2} \mathrm{O}_{3}-\mathrm{SiO}_{2}-\mathrm{Al}_{2} \mathrm{O}_{3}$ & SS & $164 \mathrm{M} \Omega$ & $34^{\circ} \mathrm{C}$ & $250^{\circ} \mathrm{C}$ & $1 \%$ \\
\hline $\mathrm{R}$ & $\mathrm{Cr}_{3} \mathrm{C}_{2}-\mathrm{Al}_{2} \mathrm{O}_{3}$ & SS & $1.91 \mathrm{E}+9 \mathrm{M} \Omega$ & $41^{\circ} \mathrm{C}$ & $965^{\circ} \mathrm{C}$ & $1 \%$ \\
\hline $\mathrm{S}$ & $\mathrm{ZrO}_{2}-\mathrm{Al}_{2} \mathrm{O}_{3}$ & $\mathrm{Al}_{2} \mathrm{O}_{3}$ & $2.18 \mathrm{E}+6 \mathrm{M} \Omega$ & $64^{\circ} \mathrm{C}$ & $1080^{\circ} \mathrm{C}$ & $2 \%$ \\
\hline
\end{tabular}

TABLE 3.-BULK PROPERTIES OF MATERIAL USED IN THIS STUDY ${ }^{4,5,6}$

\begin{tabular}{|c|c|c|c|c||}
\hline Material & $\begin{array}{c}\text { Density } \\
\left(\mathbf{g} / \mathbf{c m}^{3}\right)\end{array}$ & $\begin{array}{c}\text { Elastic } \\
\text { Modulus } \\
\left(\mathbf{1} 0^{6} \mathbf{p s i}\right)\end{array}$ & $\begin{array}{c}\text { Coefficient of Thermal } \\
\text { Expansion (CTE) }\end{array}$ & $\begin{array}{c}\text { Resistivity }(\Omega \text {-cm }) \\
\text { @ } 1100^{\circ} \mathrm{C}\end{array}$ \\
\hline Stainless Steel $(\mathrm{SS})^{4}$ & 8.02 & 28 & $17 \mathrm{ppm} /{ }^{\circ} \mathrm{C}$ & $70 \times 10^{-6}$ \\
\hline Alumina $\left(\mathrm{Al}_{2} \mathrm{O}_{3}\right)^{5}$ & 3.65 & 56 & $8 \mathrm{ppm} /{ }^{\circ} \mathrm{C}$ & $1 \times 10^{6}$ \\
\hline Silica $\left(\mathrm{SiO}_{2}\right)^{4,5}$ & 2.32 & 10 & $0.55 \mathrm{ppm} /{ }^{\circ} \mathrm{C}$ & $0.5 \times 10^{6}$ \\
\hline \begin{tabular}{c} 
Chromium Carbide $\left(\mathrm{Cr}_{3} \mathrm{C}_{2}\right)^{6}$ \\
\hline $\begin{array}{c}\text { Yttria-stabilized } \mathrm{Zirconia} \\
\left(\mathrm{ZrO}_{2} / \mathrm{Y}_{2} \mathrm{O}_{3}\right)^{5}\end{array}$
\end{tabular} & 6.7 & $>50$ & $10 \mathrm{ppm} /{ }^{\circ} \mathrm{C}$ & $80 \times 10^{-6}$ \\
\hline
\end{tabular}




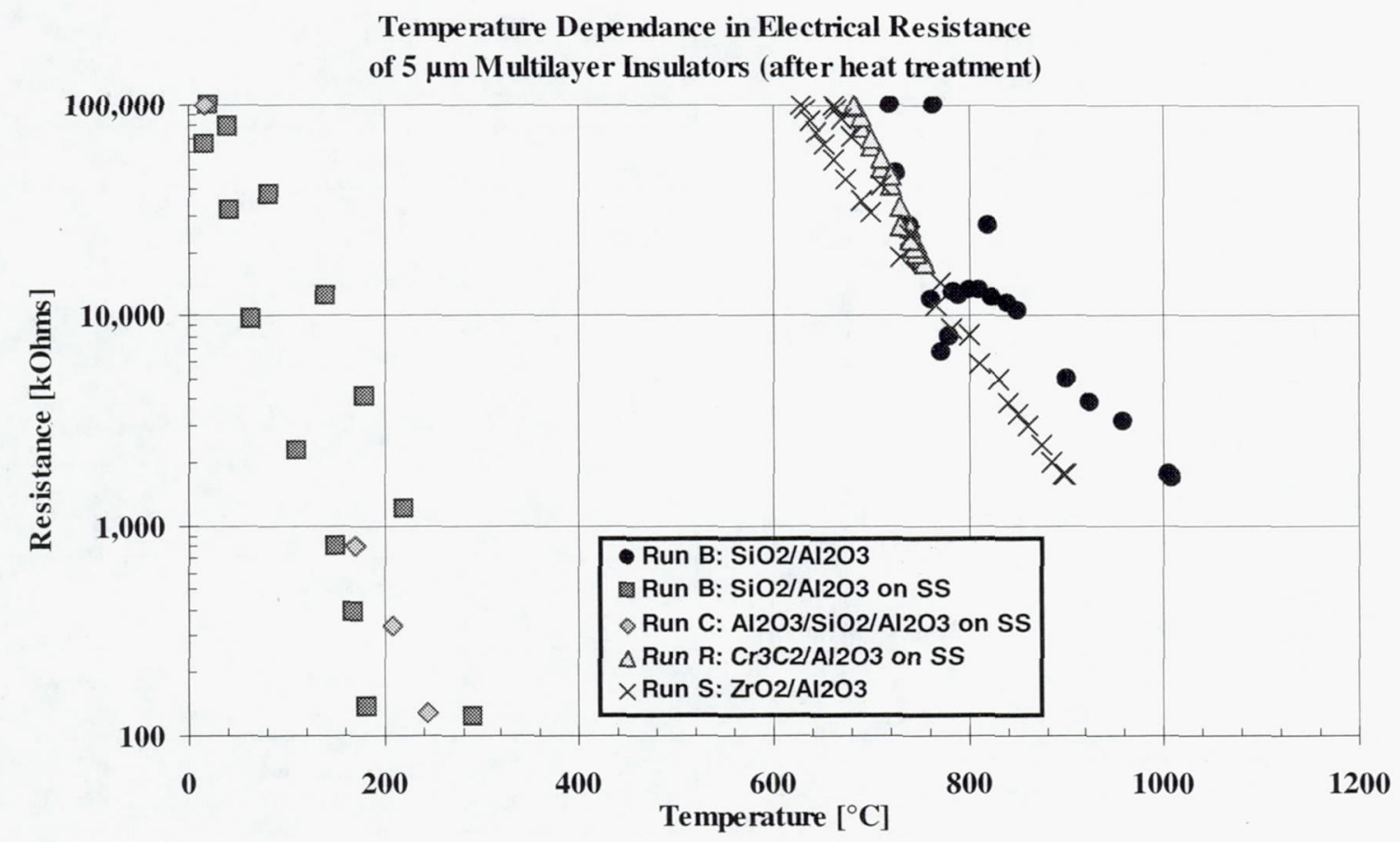

Figure 4.-Temperature dependence on electrical resistance for samples from runs B, C, R, \& S. Note the large hysteresis shown by samples from Run B. 
Public reporting burden for this collection of information is estimated to average 1 hour per response, including the time for reviewing instructions, searching existing data sources, gathering and maintaining the data needed, and completing and reviewing the collection of information. Send comments regarding this burden estimate or any other aspect of this collection of information, including suggestions for reducing this burden, to Washington Headquarters Services, Directorate for Information Operations and Reports, 1215 Jefferson Davis Highway, Suite 1204, Arlington, VA 22202-4302, and to the Office of Management and Budget, Paperwork Reduction Project (0704-0188), Washington, DC 20503. \begin{tabular}{|l|l|l|}
\hline 1. AGENCY USE ONLY (Leave blank) & 2. REPORT DATE & 3. REPORT TYPE AND DATES COVERED
\end{tabular} \begin{tabular}{|r|r|r} 
September 2002 & $\begin{array}{r}\text { Technical Memorandum } \\
\hline\end{array}$
\end{tabular}

4. TITLE AND SUBTITLE 5. FUNDING NUMBERS

A Multilayered Thin Film Insulator for Harsh Environments

6. $\operatorname{AUTHOR}(\mathrm{S})$

WU-708-73-51-00

John D. Wrbanek, Gustave C. Fralick, Charles A. Blaha, A. Rachel Busfield, and Valarie D. Thomas

7. PERFORMING ORGANIZATION NAME(S) AND ADDRESS(ES)

National Aeronautics and Space Administration

John H. Glenn Research Center at Lewis Field

Cleveland, Ohio 44135-3191

8. PERFORMING ORGANIZATION REPORT NUMBER

E-13555

9. SPONSORING/MONITORING AGENCY NAME(S) AND ADDRESS(ES)

National Aeronautics and Space Administration

Washington, DC 20546-0001

10. SPONSORING/MONITORING AGENCY REPORT NUMBER

NASA TM-2002-211873

AIAA-2002-3731

\section{SUPPLEMENTARY NOTES}

Prepared for the 38th Joint Propulsion Conference and Exhibit cosponsored by AIAA, ASME, SAE, and ASEE, Indianapolis, Indiana, July 7-10, 2002. John D. Wrbanek and Gustave C. Fralick, NASA Glenn Research Center; Charles A. Blaha, Akima Corporation, Brook Park, Ohio 44142; A. Rachel Busfield, Rolls-Royce plc, Derby DE24 8BJ, United Kingdom; and Valarie D. Thomas, Ohio Aerospace Institute, Brookpark, Ohio 44142. Responsible person, John D. Wrbanek, organization code 5510, 216-433-2077.

\begin{tabular}{|l|l}
\hline 12a. DISTRIBUTION/AVAILABILITY STATEMENT & 12b. DISTRIBUTION CODE
\end{tabular}

Unclassified - Unlimited

Subject Category: 35

Distribution: Nonstandard

Available electronically at http://gltrs.grc.nasa.gov

This publication is available from the NASA Center for AeroSpace Information, 301-621-0390.

13. ABSTRACT (Maximum 200 words)

The status of work to develop a reliable high temperature dielectric thin film for use with thin film sensors is presented. The use of thin films to electrically insulate thin film sensors on engine components minimizes the intrusiveness of the sensor and allows a more accurate measurement of the environment. A variety of insulating films were investigated for preventing electrical shorting caused by insulator failure between the sensor and the component. By alternating layers of sputtered high temperature ceramics, a sequence of insulating layers was devised that prevents pinholes from forming completely through the insulator and maintains high electrical resistivity at high temperatures. The major technical challenge remaining is to optimize the fabrication of the insulator with respect to composition to achieve a reliable high temperature insulating film. Data from the testing of various potentially insulating thin film systems is presented and their application to thin film sensors is also discussed.

\section{SUBJECT TERMS}

Insulator; High temperature; Thin film sensor; Instrumentation; Harsh environment

15. NUMBER OF PAGES 12

\begin{tabular}{|c|c|c|}
\hline $\begin{array}{c}\text { 17. SECURITY CLASSIFICATION } \\
\text { OF REPORT } \\
\text { Unclassified }\end{array}$ & $\begin{array}{c}\text { 18. SECURITY CLASSIFICATION } \\
\text { OF THIS PAGE } \\
\text { Unclassified }\end{array}$ & $\begin{array}{c}\text { 19. SECURITY CLASSIFICATION } \\
\text { OF ABSTRACT } \\
\text { Unclassified }\end{array}$ \\
\hline
\end{tabular}

